平成 30 年 7 月豪雨による愛媛県南西部の斜面崩壊に関する降雨特性の分析

\author{
小野耕平 ${ }^{1}$, 森伸一郎 ${ }^{1}$
}

1 愛媛大学・大学院理工学研究科

\begin{abstract}
概要
平成 30 年 7 月豪雨により愛媛県では多数の土砂災害が発生し,特に県南西部において甚大な被害となった。 本研究では，はじめに愛媛県南西部の豪雨の特性と斜面崩壊の特徵について整理した。続いて，県南西部 で斜面崩壊を引き起こした降雨特性について, 斜面崩壊発生地点の位置情報と, 解析雨量および XRAINに よる面的な雨量データを活用して分析した。短期降雨指標（1 時間降水量）と長期降雨指標（土壌雨量指 数）の関係を求め, 判別分析を行ったところ, 斜面崩壊が相次いだ時間帯には崩壊の有無に応じて降雨指 標の分布に有意な偏りが見られた。また，それぞれの降雨指標には斜面崩壊数が急増する境界值が存在す ることがわかり，境界值を超えた際の降水量に対する崩壊確率の増加具合は地質帯で大きく異なることが 明らかとなった。
\end{abstract}

キーワード : 斜面崩壊, 解析雨量, XRAIN, 土壌雨量指数, 判別分析

\section{1.はじめに}

2018 年 6 月 28 日から 7 月 8 日にかけて，西日本に停滞 した梅雨前線に向かって暖かく湿った空気が供給され続 けたことにより,西日本を中心に記録的な大雨となった ${ }^{1)}$ 愛媛県では，7月 5 日から 8 日にかけて県内全域で大雨と なり，多いところでは 4 日間の累積降水量が $600 \mathrm{~mm}$ を超 えるなど，複数の雨量観測所で観測記録を更新した。国土 交通省の発表 ${ }^{2}$ によると，この大雨に伴い県内で計 413 件 の土砂災害が発生し, その約 4 割の 153 件が県南西部の宇 和島市に集中した。愛媛県災害対策本部の統計 3)では計 997 件の土砂災害が確認されており，災害の有無に関係な く空中写真により認識された斜面崩壊の発生件数は数千 箇所に上るとの報告 ${ }^{4)}$ もる。土砂災害による県内の人的 被害は死者 17 名, 負傷者 23 名を数え, 人家被害は全壊 49 棟, 半壊 54 棟に上った ${ }^{2)}$ 。犠牲者数が 10 名を超える規 模の土砂災害は, 県内では過去 50 年間において 1976 年お よび 2004 年の台風を原因としたもの 5)のみであり, 今回 の被害は過去最大規模であった。

一般に，豪雨による土砂災害の発生危険度は，地質・地 形等の素因と, 降水量・降雨強度等の誘因で評価される。 誘因の評価手法の一つとして, 国土交通省と気象庁は短期 降雨指標と長期降雨指標を組み合わせた土砂災害警戒情 報 6)と呼ばれる予測システムを整備している。これは，両 降雨指標の予測值が過去の災害履歴に基づいて設定され た土砂災害発生危険基準線（Critical Line：以下，CL）に 到達すると判断された際に警戒情報を発するものである。 土砂災害警戒情報は，その有効性が既に認められているも
のの，基準である CL は一定範囲の既往の降雨と災害履歴 を基に作成されていることから, 空振り率の低下を目的と して, 各地域特性を考慮した基準值への改良が求められて いるところである。これまで，個別の土砂災害事例に対す る降雨特性を分析した研究例は多数見受けられる一方で 7)8)9，広域の土砂災害事例に対して地域特性の検討を目的 として降雨特性を比較した研究例はそれほど多くない 10)11112)。今回の豪雨では愛媛県内の広い範囲で斜面崩壊の 発生が相次いだため，その広域性から，斜面崩壊の発生密 度に加えてその誘因となる降水量には地域的な偏りが生 じていることが想定される。そのため，今回の災害は異な る地域間において斜面崩壊現象の発生誘因である降雨特 性を比較検討するのに適した事例であるといえる。

そこで本研究では, 平成 30 年 7 月豪雨における愛媛県 下の降雨特性について改めて整理するとともに, 被害が特 に甚大だった県南西部の斜面崩壊の特徴と降雨特性を分 析した。具体的には，国土地理院が発災直後に公開した空 中写真から特定した斜面崩壊発生地点の位置情報と，レー ダー雨量計による面的な雨量データを基に, 異なる地質帯 が分布する約 $1,200 \mathrm{~km}^{2}$ の範囲で斜面崩壊の発生に影響し た降雨特性を評価した。1 km および $250 \mathrm{~m}$ 四方のメッシ ユ単位で短期降雨指標と長期降雨指標の関係図を求め, メ ッシュ内における斜面崩壊の発生の有無に対して判別分 析を行った。レーダー雨量には，利用実績の多い気象庁の 解析雨量に加え, 運用年数の浅い国土交通省の XRAIN デ 一タも活用し, 両者の比較を通して土砂災害分析に対する XRAIN の適用可能性も調べた。 


\section{2. 愛媛県南西部の被害概要}

\section{1 豪雨の概要}

図 1 に 2018 年 7 月 4 日から 8 日までの期間降水量の分 布を示す。雨量データには気象庁の解析雨量 ${ }^{13)}$ を用いた。 期間降水量は，愛媛県のほぼ全域で $300 \mathrm{~mm}$ を超過してお り，中でも今治市の島嶼部や宇和島市の北部では $400 \mathrm{~mm}$ 以上，高知県との県境付近の山間部においては $600 \mathrm{~mm}$ 以 上もの降水量を記録している。今回の期間降水量と 7 月の 平年月降水量 ${ }^{14)}$ を比較すると, 今治市や松山市周辺では平 年月降水量の約 2 3 倍, 宇和島市周辺では約 2 倍に相当す る雨がわずか 5 日間で降った計算となる。愛媛県における 気象庁管轄の雨量観測所全 22 地点のうち, 24 時間降水量 は 10 地点, 48 時間降水量は 12 地点， 72 時間降水量は 11 地点で観測記録を更新した。上記 3 つの指標すべてを更新 した観測所は計 9 地点あり（大三島・今治・松山南吉田・ 長浜・中山・大洲・瀬戸 ・八幡浜・宇和), 図 1 にはこれ らの観測所の位置を黒色のプロットで, それ以外の観測所 を白抜きのプロットで示している。更新地点は県南西部の 西予市から北部の今治市の島嶼部まで主に沿岸部に沿っ て分布しており, 後述するようにこれは土砂災害が多発し たエリアと概ね対応している。降水量が例年以上となった ことが, 今回の記録的な土砂災害をもたらしたものと解釈 できる。

図 2 に土砂災害が多発した宇和島市内の雨量観測所 (宇 和島）で計測された 7 月 4 日から 8 日までの 5 日間の 1 時 間降水量, 累積降水量, 土壤雨量指数の推移を示す。土壌 雨量指数とは, 降雨による土壌中の水分量を直列 3 段タン クモデルで数值化したもの ${ }^{15)} ゙$ あり, 気象庁は土砂災害に 関する各種警報の発表基準として活用している。1 時間降 水量を 10 分間隔で等分割し, 気象庁が推奨するタンクモ デルのパラメータを用いて計算した。本論文では, 気象庁 の計算手法 6)を参考に，前後に 24 時間以上の無降雨期間 があるひとまとまりの降雨を一連の降雨とみなし, 累積降 水量および土㙵雨量指数の起算日を 2018 年 7 月 4 日 $0: 00$ に統一した。

宇和島では 7 月 5 日の朝方から雨脚が強まった。その後 一時小康状態となったものの, その夜から再び降雨が継続

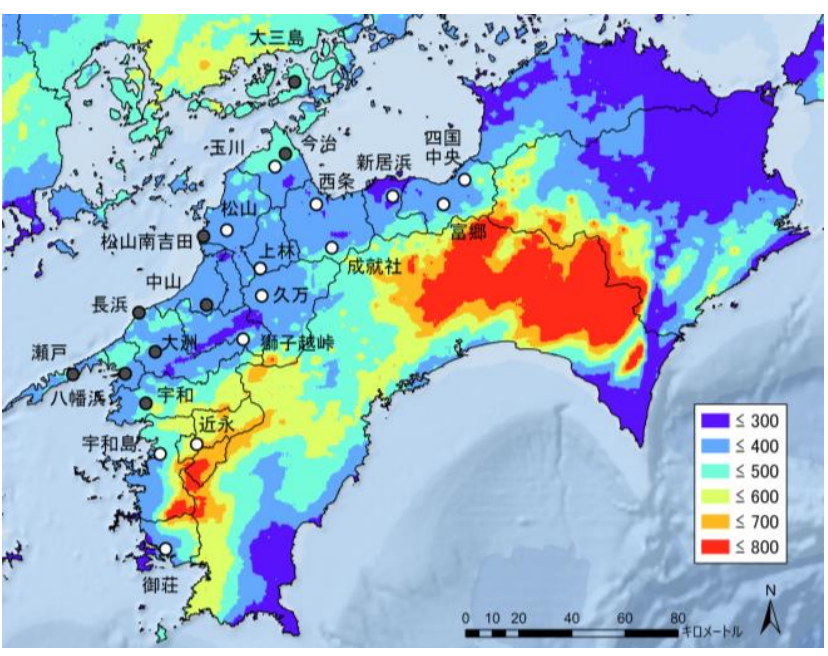

図 1 期間降水量の分布（2018 年 7 月 4 8 日）

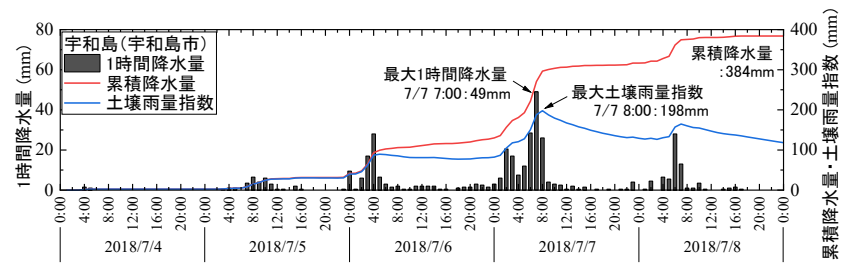

図 2 降水量の推移（2018 年 7 月 4 8 日）

し， 7 月 7 日 7:00 に期間内の最大 1 時間降水量 $49 \mathrm{~mm}$ を 記録した。同日 2:00 から 8:00 までの累積降水量 $160.5 \mathrm{~mm}$ は 5 日閒の累積降水量 $384 \mathrm{~mm} の 4$ 割以上に相当し，土砂 災害の多くがこの降雨ピーク後に集中したことがわかっ ている ${ }^{16)}$ 。本論文では，県南西部におけるこの時間帯にお ける降雨特性と土砂災害の関連について後述する。宇和島 では翌朝の 8 日にも降雨ピークが確認されており，8 日 5:50 には愛媛県では制度施行後初めて大雨特別警報が発 表されている ${ }^{17)}$ 。

各地で降雨ピークが観測された 7 月 7 日の 6:00から 8:00 にかけて, 解析雨量による 1 時間降水量の推移を図 3 に示 す。 $6: 00$ 時点では県南部の一帯で $30 \mathrm{~mm}$ を越える雨量を 計測しており, 西予市南部から宇和島市北部の一部の地域 では $50 \mathrm{~mm}$ を超えるような非常に激しい降雨となってい る。その後, 7:00 時点では宇和島市北部の広い範囲で雨量
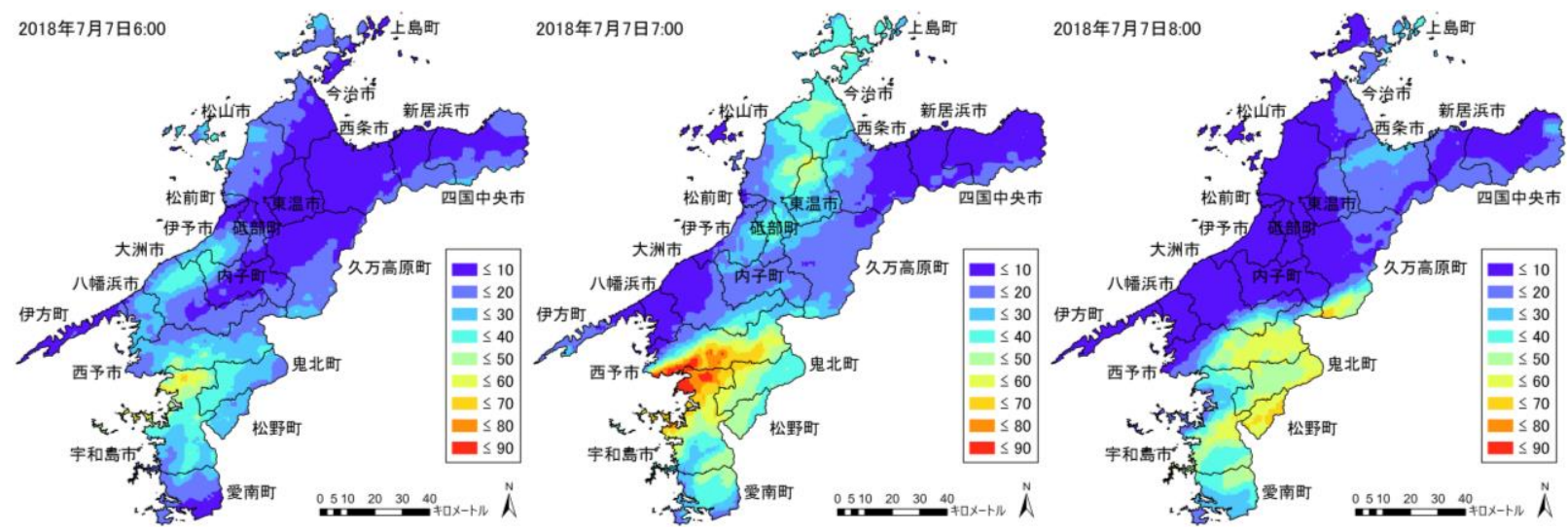

図 31 時間降水量の推移（7 月 7 日 6:00 8:00） 
が大幅に増加し，一部では $90 \mathrm{~mm}$ を超える猛烈な雨を観

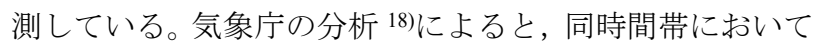
周辺に線状降水帯の形成が認められている。また同時刻に は，今治市から松山市にかけての広い範囲においても 30 $\mathrm{mm}$ から $50 \mathrm{~mm}$ 程度の激しい降雨となっている。その後, 8:00には宇和島市北部の 1 時間降水量は $30 \mathrm{~mm}$ 程度まで, 今治市周辺も $20 \mathrm{~mm}$ 程度まで落ち着いており, 猛烈な降 雨を短時間に経験したことがわかる。この短時間での豪雨 が愛媛県における過去最大規模の土砂苂害の発生誘因で あることは明らかであるものの，7月 4 日から断続的に降 り続いた長雨の影響も無視できない。数日間にわたる降雨 によって斜面が不安定化した後に, 短時間の記録的な豪雨 を経験したことが被害を拡大させたものと推察され，長期 的な降雨と短期的な降雨が複合的に影響した結果である といえる。

\section{2 斜面崩壊の概要}

愛媛県を含む四国地方の地質は東西に帯状に分布して おり, 平行する 3 つの構造線によって 4 つ地質帯に大区分 される 19)。図 4 に示す通り, 中央構造線より北側は領家帯 と呼ばれ, 南側は, 御荷鉾構造線, 仏像構造線によって, 北側から三波川帯, 秩父帯, 四万十帯が分布する。Mori and $\mathrm{Ono}^{20)}$ は, 国土交通省がまとめた県内全 20 市町の土砂災害

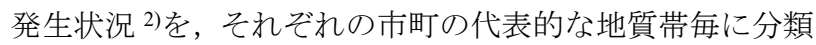
して評価した。その結果，四万十帯における土砂災害発生 件数が全体の約 4 割を占めていること, 土石流およびがけ 崩れはいずれの地質帯でも発生している一方で, 地すべり は三波川帯でのみ確認されていることを示し, 土砂災害の 発生件数や斜面の崩壊形態は地質帯に依存している可能 性を指摘した。本論文では被害が特に甚大だった県南西部 に対象を絞り，この土砂災害の地質帯による発生数と発生 形態に見られる偏りについてより詳細な分析を行う。

国土地理院は，被害状況の把握を目的として，発災直後 の 2018 年 7 月 11 日に, 図 4 に示寸大洲市から宇和島市に かけての約 $1,200 \mathrm{~km}^{2}$ の範囲において空中写真 (正射画像) を撮影した。国土地理院は崩壊の長さまたは幅が $50 \mathrm{~m}$ 以 上という基準で斜面崩壊地を判読し，崩壊地等分布図 ${ }^{21)}$ として 7 月 19 日に公開した。国土地理院は合流する複数 の崩壊も一括してカウントしており, 崩壊数を過小評価し ている可能性があったため, 川崎・森 ${ }^{22}$ は空中写真を基に 崩壊地点の特定作業を改めて行った。その結果, 空中写真 の範囲内において図 4 に示す 882 箇所の斜面崩壊地点を特 定した。図中の格子は約 $1 \mathrm{~km}$ 四方の基準地域メッシュ（第 3 次メッシュ）を表しており，海上を除いた判読範囲内の 合計メッシュ数は 862 個である。図 4 より, 崩壊地点の分 布には偏りがあり, 西予市南部から宇和島市北部にかけて の沿岸部に崩壊地点が集中していることが見て取れる。

判読範囲内の地質帯は, 北側から三波川帯, 秩父帯, 四 万十帯の 3 地質帯に大別される。表 1 に, 地質帯毎にカウ ントした斜面崩壊数, メッシュ数, 崩壊密度を示す。メッ

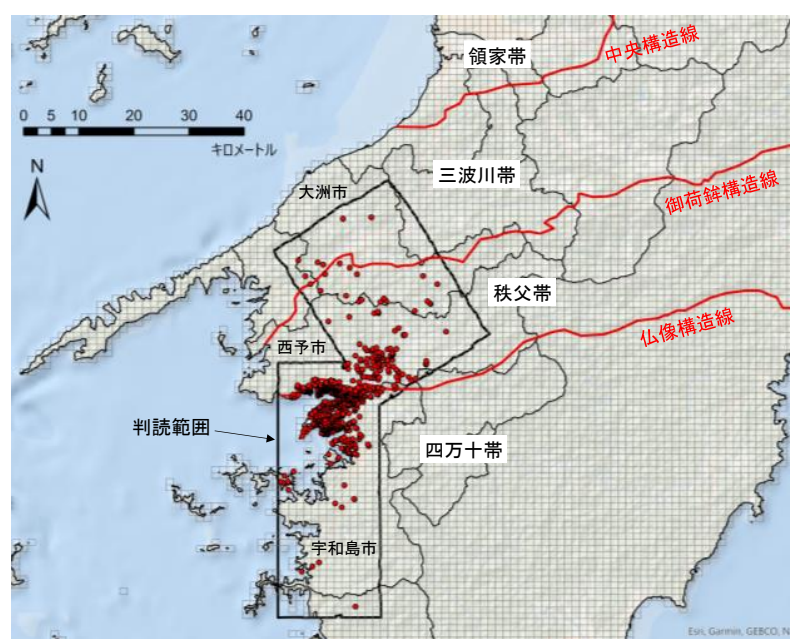

図 4 地質帯の分類および崩壊地点の分布

表 1 判読範囲内の崩壊数等

\begin{tabular}{|c|c|c|c|c|}
\hline 地質帯 & $\begin{array}{l}\text { 崩壊数 } \\
\text { (籄所) }\end{array}$ & $\begin{array}{c}\text { メッシュ数 } \\
\text { (個) }\end{array}$ & $\begin{array}{c}\text { 崩壊密度 } \\
\left(\text { 箅所 } / \mathrm{km}^{2}\right)\end{array}$ & $\begin{array}{c}\text { 最大崩壊密度 } \\
\left(\text { 筫所 } \mathrm{km}^{2}\right) \\
\end{array}$ \\
\hline 三波川帯 & 6 & 165 & 0.04 & 1 \\
\hline 秩父帯 & 147 & 371 & 0.40 & 8 \\
\hline 四万十帯 & 729 & 326 & 2.24 & 43 \\
\hline 全体 & 882 & 862 & 1.02 & 43 \\
\hline
\end{tabular}

シュ単位の地質帯の分類は， 20 万分の 1 日本シームレス 地質図 $\mathrm{V}^{23}$ )を参考に決定した。ここで，崩壊密度の定義 は，それぞれの地質帯毎の合計崩壊数を合計メッシュ数で 除したものとした。基準地域メッシュは約 $1 \mathrm{~km}$ 四方であ るため, 崩壊密度は単位面積当たりの平均的な崩壊数を表 す。地質帯毎の崩壊密度は四万十帯で高く, 三波川帯の崩 壊密度の 56 倍, 秩父帯の 5.6 倍に達している。また, 1 メ ッシュ当たりの最大崩壊数を表す最大崩壊密度も四万十 帯で 43 箇所 $/ \mathrm{km}^{2}$ と極端に高く, 今回の豪雨による斜面崩 壊の発生密度には地質帯毎に大きな偏りが認められる。

その一方で,ここでは斜面崩壊の発生誘因である降水量 の多臭は考慮されていない。そこで, 空中写真から特定し た上述の斜面崩壊発生地点の位置情報と, 気象レーダーに よる同地点の雨量データを組み合わせて検討することで, 斜面崩壊の発生に直接関連する降雨特性について次章で 考察する。なお, 地質以外の地形や植生等の個々の斜面の 素因の影響についてはここでは議論の対象とせず, 本論文 では広く地質帯に着目して降雨特性と併せた検討を行う。

\section{3. 斜面崩壊に影響する降雨特性の検討}

\section{1 斜面崩壊に寄与した降雨の絞り込み}

一般に, 降雨に伴う斜面崩壊の発生は雨水の浸透による 地盤内の水分量の上昇具合に左右されるため, 崩壊発生時 点の降水量のみでは安定性の評価や崩壊の予測を行うこ とは難しいとされる 24)。すなわち, 崩壊発生時の降水量に 加えて先行降雨の影響も重視され, 前者を短期降雨指標, 
後者を長期降雨指標とした複合的な評価手法がこれまで 提案されてきた。先述の国土交通省と気象庁の土砂災害警 戒情報は 1 時間降水量と土壤雨量指数を組み合わせた評 価手法であり，また，Nakai et al. ${ }^{25}$ は短期実効雨量と長期 実効雨量を組み合わせた “雨量指標”を提案している。こ こでは土砂災害警戒情報の手法にならい, 短期降雨指標と して 1 時間降水量を, 長期降雨指標として土壌雨量指数を 採用し，評価を試みる。

雨量データには, 気象庁の解析雨量に加えて, 国土交通 省が運用する XRAIN ${ }^{26)}$ を利用した。XRAIN は，Xバンド 周波数の MP レーダーを用いた雨量観測システムであり, 高頻度かつ高い空間分解能で降雨強度を計測することが できる。その一方で，XRAIN は運用開始からの年数が浅 く, 土砂災害を対象とした定量的な評価に活用された研究 例は少ない。そのような背景から，両者のデータを用いて 同様の分析を行うことでその特徴を検証した。今回使用し たXRAIN データの取得間隔は 10 分, 計測点は約 $250 \mathrm{~m}$ 四 方の 4 分の 1 地域メッシュに対応しており，すなわち解析 雨量と比較して, 6 倍の時間解像度および 16 倍の空間解 像度である。

はじめに, 各雨量データの整合性を確認する目的で, 図 4 の判読範囲内に位置する雨量観測所の地上雨量と, その 地点が含まれるメッシュの解析雨量および XRAIN を比較 する。図 5 に大洲（大洲市）と宇和島（宇和島市）の 2 箇 所の雨量観測所地点における土䁃雨量指数と 1 時間降水 量の推移 (スネーク曲線) を示す。ここで，XRAIN は 10 分間隔の瞬間的な降雨強度であるため, 気象庁アメダスな どの観測データと同様に扱うように 60 分間ごとの降水量 を求め， 1 時間降水量と土壇雨量指数の計算に用いた。グ ラフから，3 者のデータはばらつきを含むものの，1 時間
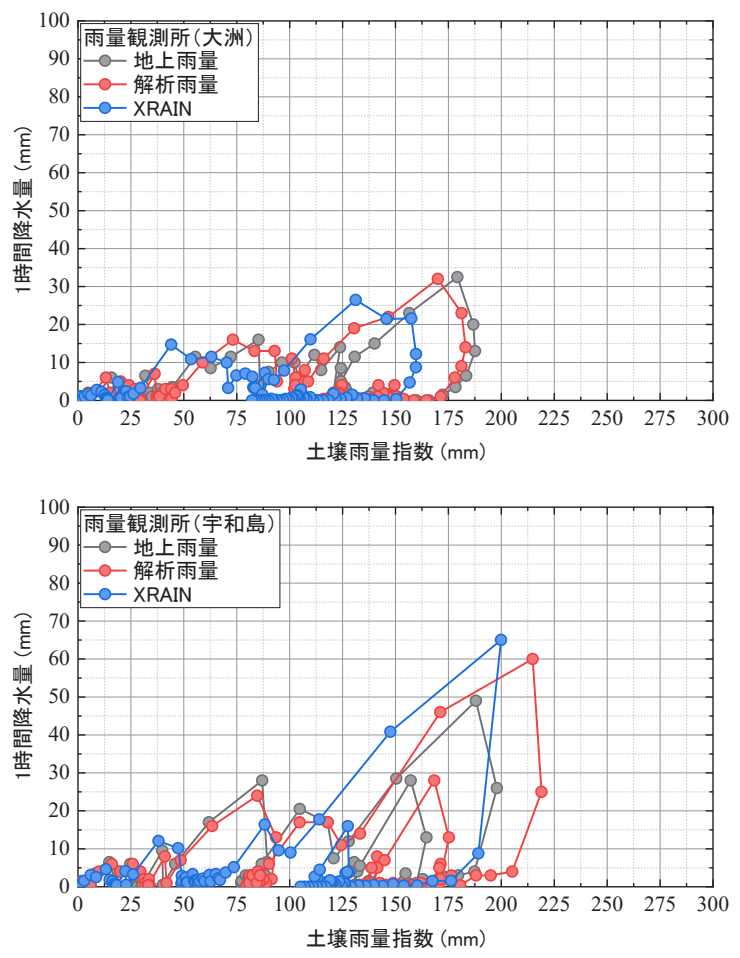

図 5 地上雨量・解析雨量・XRAIN のスネーク曲線の比較
降水量と土畩雨量指数の増減のトレンドは概ね整合して いると判断できる。その中で，土壌雨量指数は XRAIN が

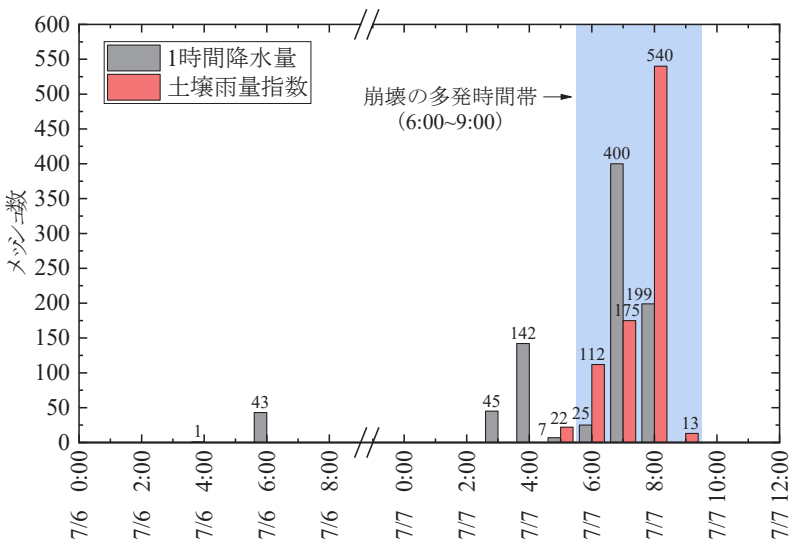

図 6 各降雨指標最大值の頻度分布

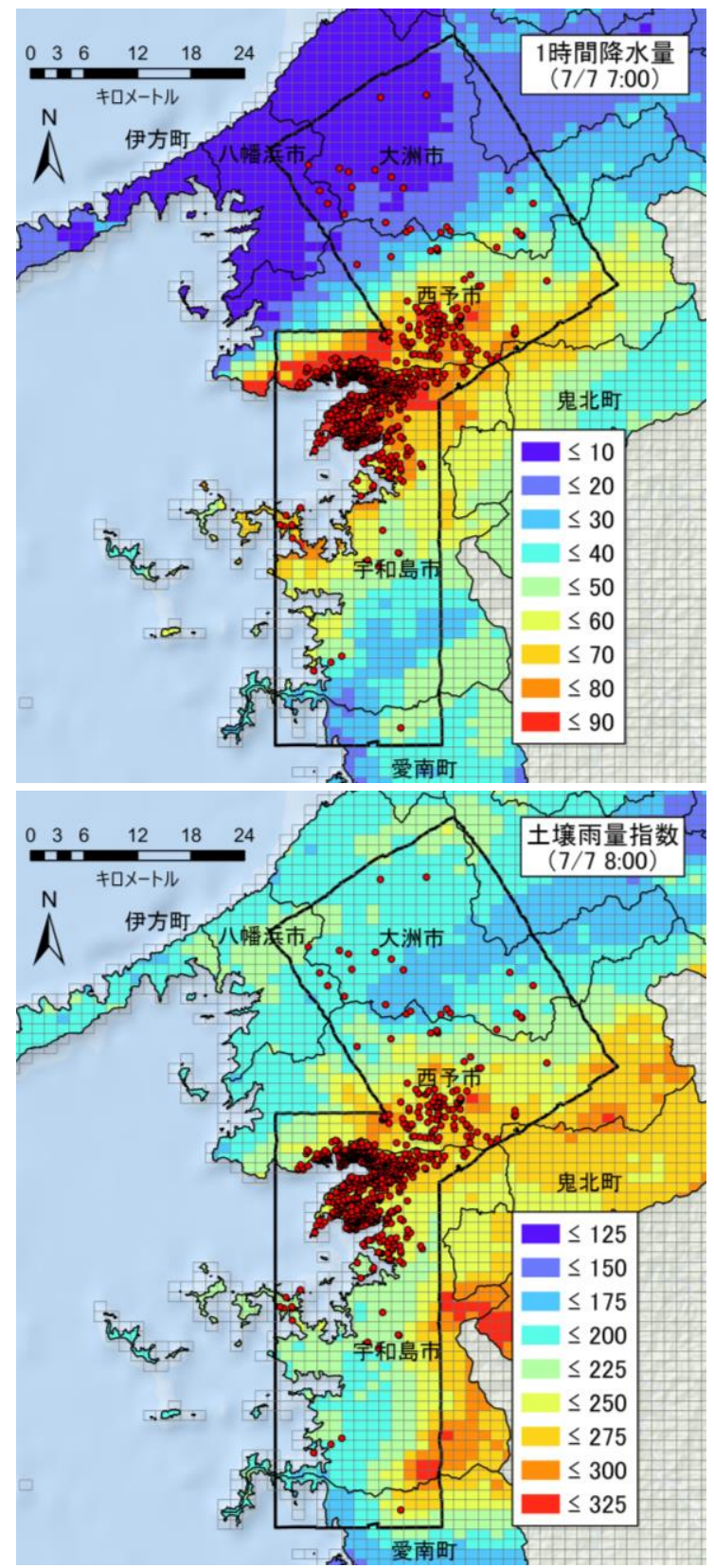

図 71 時間降水量・土褰雨量指数の分布 
やや低い值を示す傾向にある。この原因として，XRAIN は瞬間的な降雨強度を降水量に変換していることに加え, 地上雨量に対してやや過小傾向にあるため 27)であると推 察される。土壌雨量指数は 1 時間降水量を基に計算される ため, 1 時間降水量の差の積み重ねが土壤雨量指数の過小 評価に繋がったものと考えられる。

続いて, 斜面崩壊の発生に寄与した一連の降雨イベント を絞り込むため, 判読範囲内の基準地域メッシュ 862 個を 対象に, 解析雨量から求めたそれぞれの降雨指標が最大と なった時刻を調べた。図 6 にそれぞれの最大值の頻度分布 を示す。 1 時間降水量の最大值は 7 月 7 日 4:00 から 8:00 の間に集中しており, 約半数のメッシュ (400 箇所) で 7:00 に最大值を記録している。一方, 土壌雨量指数の最大值は その寸べてが 7月 7日 5:00から 9:00の間に分布しており， 6 割以上のメッシュ（540 箇所）で 8:00 に最大值を記録し ている。そこで, 図 7 に 7 月 7 日 7:00 時点の 1 時間降水 量分布と, 8:00 時点の土壤雨量指数分布を示す。図 7 より, 斜面崩壊が集中した西予市南部から宇和島市北部の一帯 において 1 時間降水量, 土壌雨量指数ともに相対的に高い ことがわかる。一方で, 両降雨指標がともに低い大洲市や 宇和島市の南部では, 斜面崩壊の発生地点もまばらである。 人的被害が多数生じた宇和島市の北部では, 7 月 7 日の 6:00 から 9:00 にかけて土砂災害が同時多発したことが明 らかとなっており 16), 両降雨指標の高まりと斜面崩壊の発 生には強い相関がうかがえる。

\section{2 土壤雨量指数と 1 時間降水量の時間変化}

前述の土砂災害警戒情報の判定手法を参考に, 判読範囲 内の全領域において土壌雨量指数と 1 時間降水量の関係 を求めた。斜面崩壊した 882 地点全ての崩壊時刻は不明で あるため, 判読範囲内の宇和島市北部で崩壊が多発したと
される時間帯 16)の前後数時間における両降雨指標の関係 を求め, その特性を調べた。

図 8, 図 9 に 7 月 7 日 5:00 8:00 における全メッシュの 土壤雨量指数と 1 時間降水量の関係 (以下, SWI-HR 関係) を示す。解析雨量の総メッシュ数は 862 個, XRAIN は 12,632 個である。ここで, 図中のプロットは各メッシュ内 の崩壊発生の有無に応じて区別した。なお, 対象メッシュ 内で 1 箇所以上の崩壊が発生していれば崩壊有のメッシ ユとして分類しており，ここでは崩壊数の多臭や崩壊の規 模は考慮していない。

ここで斜面の崩壊現象は, 素因が崩壊を引き起こす条件 を満たした上で誘因がある一定の值（閾值）を超えた時に 発生するという観点から, 閾值現象 (Threshold phenomena) とみな寸ことができる。したがって, 斜面崩壊をばらつき のある不確定現象とみなすと, 崩壊と非崩壊を分ける統計 的な判別分析が有効である。そこで, 図 8 と図 9 の SWI-HR 関係図における分布の差異を定量的に評価するため, 崩壊 有・崩壊無の二つのデータ群に対して Fisherの線形判別分 析と Mahalanobis 距離を用いた 2 次判別分析を実施し, 二 つの判別分析の境界線（以下，判別境界線）をそれぞれ黒 線, 赤線で図中に示した。

図 8 に示寸解析雨量を用いた SWI-HR 関係図では, 5:00 時点では両群のプロットがともに中央下部に重なって分 布しており, 崩壊の有無で分布に差異は見られない。6:00 時点では, 縦軸の 1 時間降水量にばらつきが大きくなって いるものの, 崩壊の有無で分布に明瞭な差はない。一方, 7:00 時点では, 土壤雨量指数の増加に応じて分布が横軸方 向に大きく拡大し, 崩壊が発生したプロット群はその多く が右上方に偏り, 一部が左下方に分布している。その後, 8:00 時点では土壤雨量指数はさらに上昇し, 崩壊群の多く は土壤雨量指数の大きい右側に偏っている。SWI-HR 関係
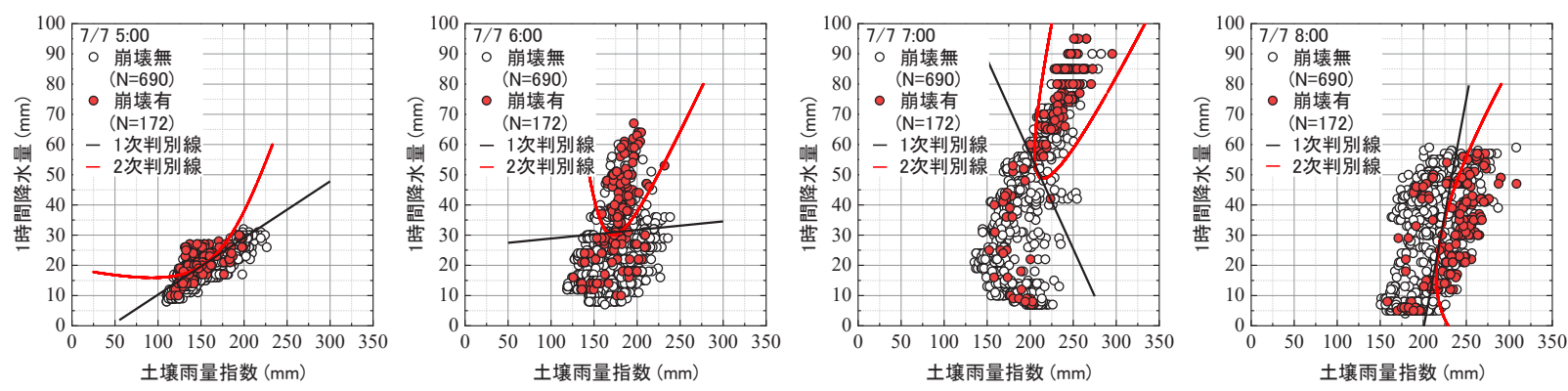

図 8 土壌雨量指数と 1 時間降水量の関係（解析雨量）
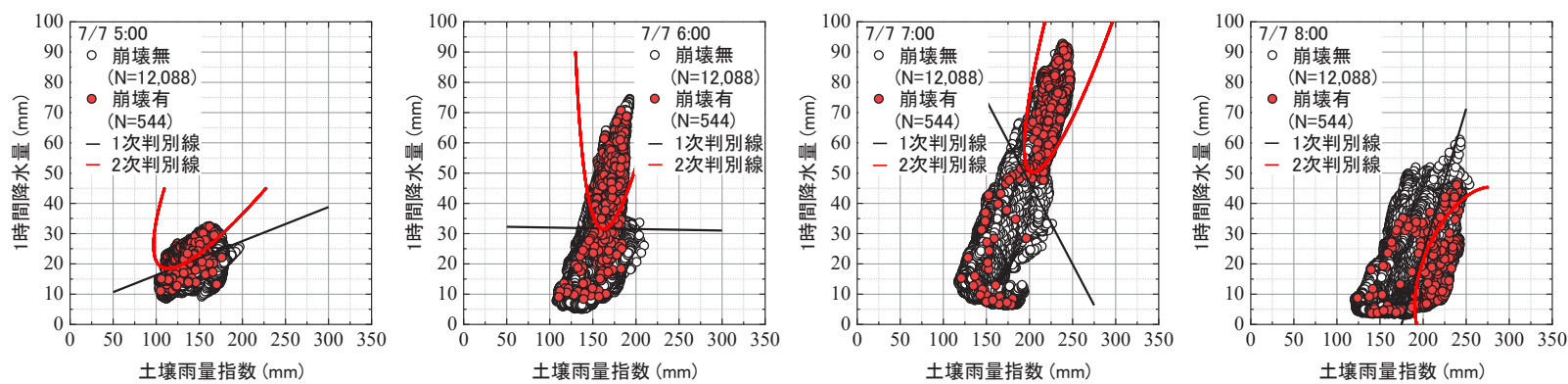

図 9 土㙥雨量指数と 1 時間降水量の関係 (XRAIN) 
図において，5:00 と 6:00 では判別の適否を判断すること は難しいものの，7:00 8 8:00 では判別境界線の外側（原 点から遠ざかる方向）に密集して分布する崩壊群と, 判別 境界線より内側に散在する崩壊群が確認できる。後者の内 側に散在する崩壊群に関しては，次節で考察する。

図 9 には XRAIN のレーダー雨量を用いた分析による SWI-HR 関係図を示す。解析雨量を用いた分析結果と比較 してプロット数は圧倒的に多いが, プロットされる範囲や 二つの判別境界線は非常に似通っていることがわかる。特 に, 7:00 時点と 8:00 時点では, 判別境界線の外側の崩壊 群が密集している様子が図 7 に比較してより明瞭である。

判別境界線の外側の崩壊群の密集は, 斜面崩壊が閾値現 象であり, 判別境界線が䦨值そのものであることを反映し ていると考えられる。そこで, 閾值現象としてのこれらの 判別分析の適用性について検討する。一般に, 判別分析の 精度は陽性的中率で議論されることが多いが，2 群のサン プル数の比に応じて陽性的中率は大きく変化する。特に, 今回の XRAIN データのように崩壊無のメッシュ数が崩壊 有のメッシュ数に対して極めて多い場合, 陽性的中率は著 しく低下する。そこで, 判別分析の特性として感度に着目 する。感度は，真陽性数/陽性数（=真陽性数+偽陰性数） と定義され，ここでの真陽性数とは判別式で崩壊と判別さ れた崩壊有のメッシュ数であり, 陽性数とは崩壊有のメッ シュ数である。よって，感度を用いれば，崩壊無のメッシ ユ数に関係なく判別の精度を評価することが可能である。

図 10 に二つのデータセットに対する時刻別の感度を示 す。いずれの雨量データ, 判別分析手法においても, 感度 は7:00 時点で急上昇して最大となり, 8:00はそれに続く。 前述の崩壊群の密集度合いと併せ考えると, この時間帯に おいて崩壊有・崩壊無の両群の分布に有意な差が現れたと いえる。すなわち，二つの判別式は斜面崩壊という閾值現 象の判別に対して 7:00 時点および 8:00 時点で適用性が高 いと判断できる。先述の一部の明確な崩壊発生時刻 16) との 整合はこの考察を裏付けるものであり，すなわち，多くの 地点でこの時間帯に崩壊が発生した可能性が高いと推定 できる。

ここで，SWI-HR 関係図上に描かれる一般的な CL を参 考にすれば, 図 8 と図 9 に示した 7:00 と 8:00の二つの時

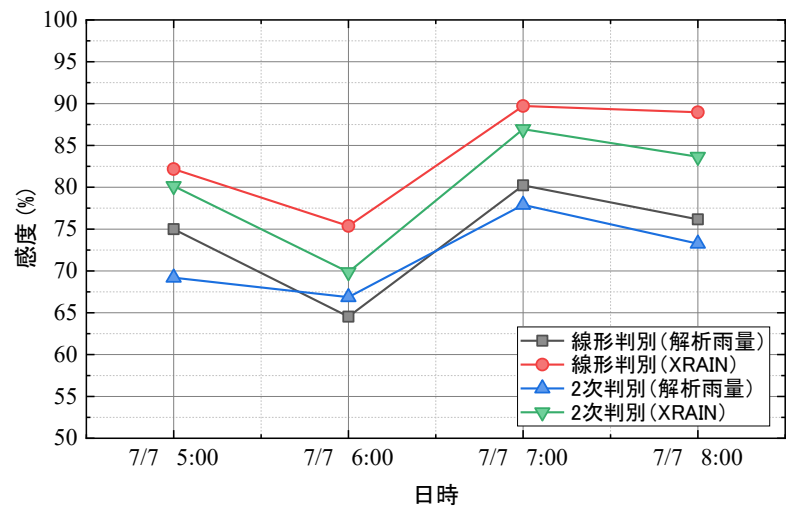

図 10 判別分析による時刻別の感度
点の判別境界線に沿うように, 土壌雨量指数 $200 \mathrm{~mm}, 1$ 時間降水量 $50 \mathrm{~mm}$ 付近を通る曲線を想定することができ る。この曲線は, 崩壊群の密集に対する代表的な判別境界 線であり，すなわち，この領域一帯における代表的な CL として捉えることができる。なお，5:00 時点と 6:00 時点 の崩壊群の多くはこの想定される CL の内側に位置してお り，感度も 65 82\%とある程度は高い。しかしながら，判 別境界線は判別分析の精度にかかわらず数学的に求めら れるため, その有意性は両群の分布の様子も含めて判断す べきである。SWI-HR 関係図の両群は全体的に重なって分 布していることを加味すると, これらの時刻の感度には工 学的な意味はないと理解できる。工学的に意味を持つ 7:00 時点および 8:00 時点の感度は, 2 次判別よりも線形判別が 高いこと，解析雨量よりも XRAIN が格段に高いことが特 筆すべき点であり，空間分解能が高い XRAIN の有用性が 示された結果であるといえる。

\section{3 地質帯別の分析}

感度が最も高く, 崩壊が多発した可能性が高い 7 月 7 日 7:00 時点を分析の対象として, 地質帯別に同様の検討を試 みる。図 11 と図 12 に，解析雨量と XRAIN の SWI-HR 関 係図をそれぞれ示す。各地質帯の特性を評価する指標の一 つとして，図中には CL を破線で示した。CL は愛媛県砂 防部局 28)によって基準地域メッシュ毎に設定されており， それらから対象メッシュ領域内の最大と最小のCL を地質 帯別に抽出した。CL は一定の広がりを有する地域毎に降

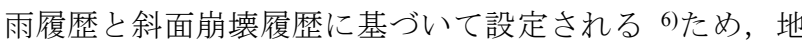
形・地質の影響は間接的に反映されている。各地質帯で, 最大と最小の CL には土壤雨量指数と 1 時間降水量ともに 1.5 倍から 2 倍程度の差があることから，同一の地質帯で あっても斜面崩壊の起こりやすさは経験的に異なること が示されている。また，秩父帯の最大 CL は他の地質帯に 比較してやや小さいものの, 同一の地質帯でのばらつきを 考えると顕著な差ではない。崩壊有・崩壊無の両群の分布 は地質帯で大きく異なり，解析雨量と XRAIN を比較する と，後者の方が分布傾向は明瞭である。したがって，以下 の考察は主にXRAIN に着目したものである。

三波川帯では, 崩壊が発生したメッシュ数が 6 箇所と極 めて少なく，それらの地点の 1 時間降水量は $10 \mathrm{~mm}$ 程度 と少ないことが特徵的である。図 4 で認められた斜面崩壊 は主にがけ崩れや土石流に分類されるものであるが，その 一方で三波川帯は県内で地すべりが発生している唯一の 地質帯である 20)。したがって，1 時間降水量が少ない場合 であっても累積降水量が闇值を超えることで崩壊に至る という，地すべりを起こしやすい地質に特有の性質を持っ ている可能性がある。

四万十帯では，先に示した全地点の分布に比較して，関 係図右上方の崩壊群の密集が一層明瞭になる。崩壊プロッ 卜はいずれも最小 CL の外側に分布しており，現在設定さ れているCL の妥当性が示されている。 

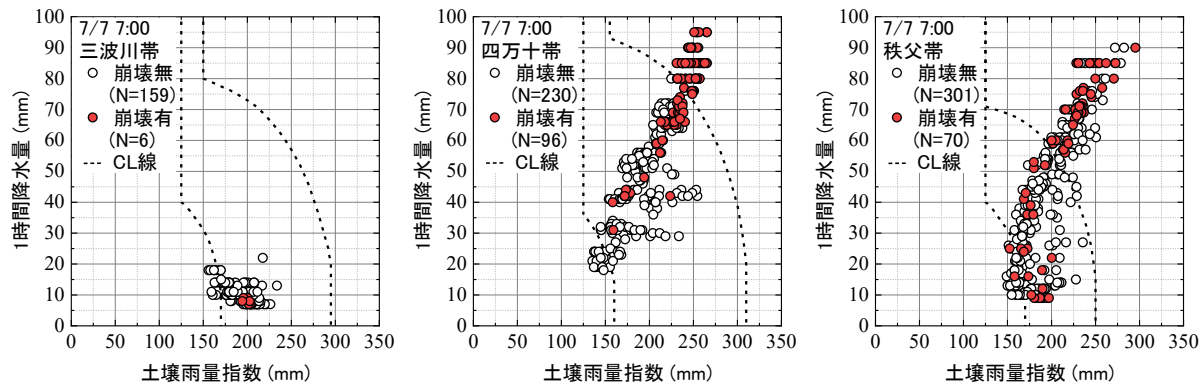

図 11 地質帯毎の土壌雨量指数と 1 時間降水量の関係（解析雨量）
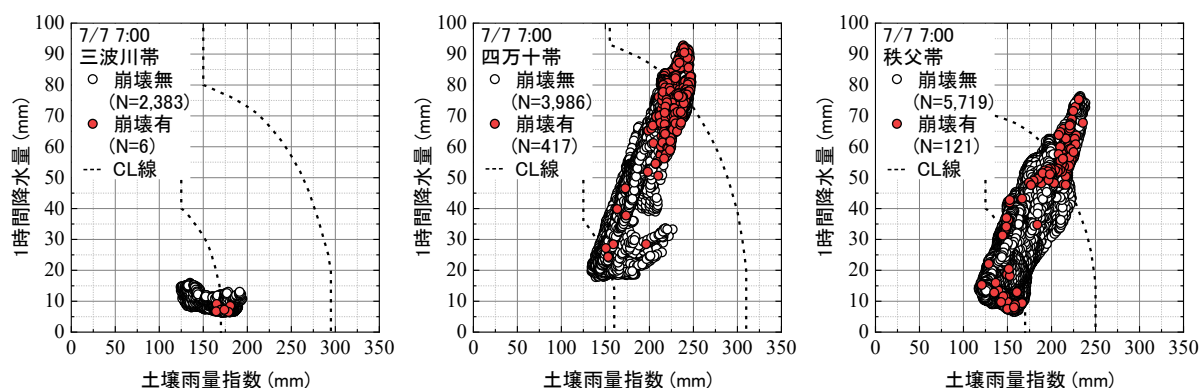

図 12 地質帯毎の土壤雨量指数と 1 時間降水量の関係（XRAIN）

秩父帯では, 関係図右上方と左下方に分布する二つの崩 壊群が特徵的である。前者の崩壊群に対して想定される判 別境界線は，秩父帯の代表的な CL に相当するものと考え られ, 四万十帯と似ている。一方, 後者の崩壊群は秩父帯 の中でも最も脆弱な地点を表すものとして捉えることが できるが，その一部は現在設定されている最小 CL の内側 にも分布している。内側に分布する地点の雨量の推移を確 認したところ，この前後数日間において 1 時間降水量が $30 \mathrm{~mm}$ 以上を記録した時間帯は無かったことから, 他の時 間帯の豪雨によって崩壊が発生したとはいえない。そこで, 秩父帯の崩壊地点における 7 月 7 日 7:00 時点の 1 時間降 水量の分布を図 13 に示す。図より, 1 時間降水量が $30 \mathrm{~mm}$ 未満の崩壊地点は三波川帯に近い北側の一帯でのみ分布 していることが特徵的である。先述の通り，三波川帯では 地すべり型の崩壊が複数確認されていることから, この一 帯ではそれに近い地質特性を有している可能性が考えら れる。また, 地質以外の素因として, 斜面勾配や集水面積 の影響も想定され, この代表的な崩壊群の密集がどのよう な地質や地形に対応するのかを明らかにすることは今後 の課題である。

\section{4 降雨指標の定量評価}

ここまで, 斜面崩壊を䦨值現象として捉え, その䦨值と して CL が読み取れることを示した。一方で，これは斜面 崩壊の発生・非発生を分ける両降雨指標の統計的な分析で あり, 斜面崩壊の発生密度は評価できない。土砂災害のリ スクを考える上で, 斜面崩壊の程度を表す発生密度を評価 することは発生・非発生の評価の次に重要である。そこで, 各降雨指標の幅と崩壊密度の関係を基に斜面崩壊のリス クに関する確率指標を議論する。なお本節では, 斜面崩壊

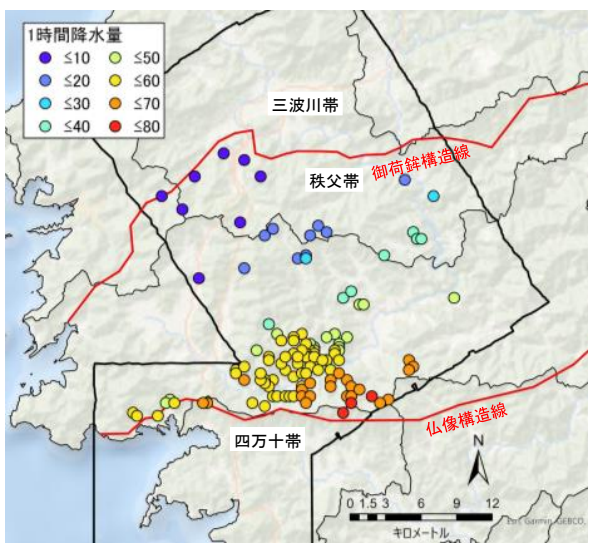

図 13 秩父帯崩壊メッシュの 1 時間降水量の分布

発生地点の降雨特性に違いが見られた秩父帯と四万十帯 に対象を絞る。

図 14 に地質帯毎の崩壊密度と 7 月 7 日 7:00 時点の 1 時 間降水量の幅 $(20 \mathrm{~mm})$ および土壤雨量指数の幅 $(40 \mathrm{~mm})$ との関係を示す。ここでの崩壊密度は，対象の降雨指標が 記録されたメッシュ内における合計崩壊数をその合計メ ッシュ数で除した平均的な崩壊数を表している。なお，こ こでは解析雨量の場合についてのみ示している。

両地質帯ともに二つの降雨指標の幅と崩壊密度には単 調増加の傾向があり，ともに 1 時間降水量が 60 80 mm よ り，土壤雨量指数が 220 260 mm より崩壊密度は急増して いる。各降雨指標の境界值は両地質帯で等しく, 前節で示 した判別境界線の外側に位置する崩壊群の密集分布が同 様の位置にあったことと調和的である。

一方，この境界值以上では，いずれの降雨指標でも四万 十帯の方が崩壊密度は極めて高い。特に土壌雨量指数 260 300 mm の範囲では両地質帯で約 9 倍もの開きが見ら 

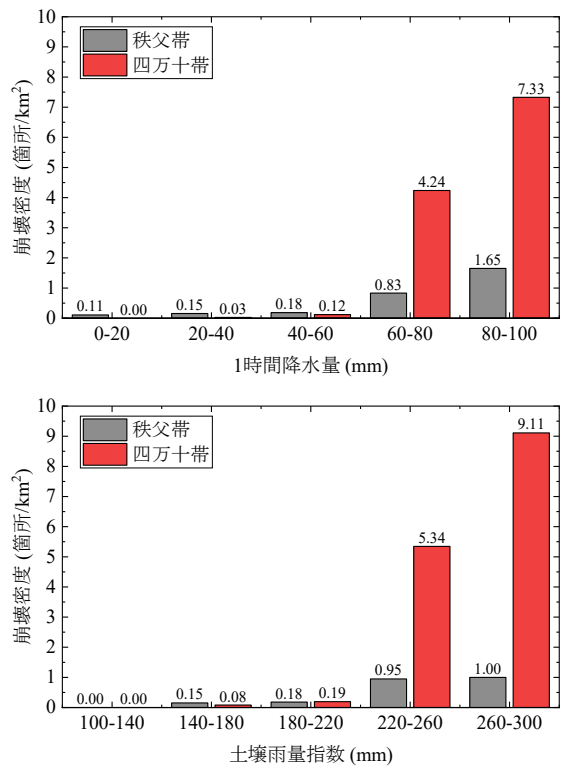

図 14 各降雨指標と崩壊密度の関係（7月 7 日 7:00）

れ, 境界值を超えた際の降水量に対する崩壊確率の増加具 合は地質帯で大きく異なることが示されている。ここで, 地盤工学的な視点からは, 境界值を超えた場合の四万十帯 での破壊現象の急増は, 斜面を形成する岩盤の脆性破壊を 反映したものであると推察される。たとえば，木村ら ${ }^{29)}$ は四万十帯での詳細な現地調査を通して, 風化砂岩に見ら れた特徵的な節理の発達が斜面崩壊の多発に繋がった可 能性を指摘しており, 脆性破壊特性の一つのメカニズムと して考えられる。今後, 斜面崩壊につながる各地質に特有 の降雨特性を明らかにすることにより, 素因と誘因の両者 を組み合わせた総合的な評価手法の開発を進めていく必 要がある。

\section{5 大雨警報（土砂災害）基準値の評価}

気象庁の定める大雨警報（土砂災害）は，重大な土砂災 害が発生する可能性が高まった際に警戒を呼びかけるも のであり，過去の災害発生事例を網羅的に調査した上で, $1 \mathrm{~km}$ 四方の基準地域メッシュを単位とした土䁃雨量指数 の基準值が設定されている。すなわち，この警報基準值は, 過去の災害履歴が考慮された斜面の降雨への耐性を示す 一種の指標であると考えられる ${ }^{30)}$ 。そこで，ここでは解析 雨量から求めた土壌雨量指数と警報基準值の比較を行い, 警報基準值を評価した。なお，より上位の特別警報の発表 基準值は市町村単位での夕公開されているため, 空間分解 能の高い大雨警報基準值を評価に用いた。

図 15 に災害発生以前の 2010 年に設定された大雨警報 (土砂災害) 基準值 ${ }^{31)}$ の愛媛県内の分布を示す。基準值は 平年降水量の多い山間部では高く, 降水量の少ない県北部 の島嶼部や県南部の宇和島市の沿岸部では低く設定され ており,これまでの降雨履歴や災害履歴が反映されている ことが確認できる。大洲市から宇和島市にかけての判読範 囲内の警報基準值は，県平均值である $155 \mathrm{~mm}$ と比較して

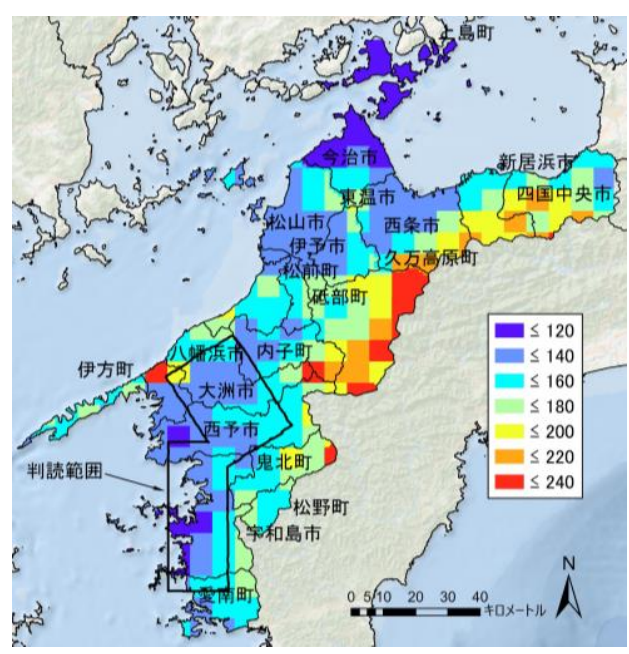

図 15 大雨警報（土砂災害）基準値の分布

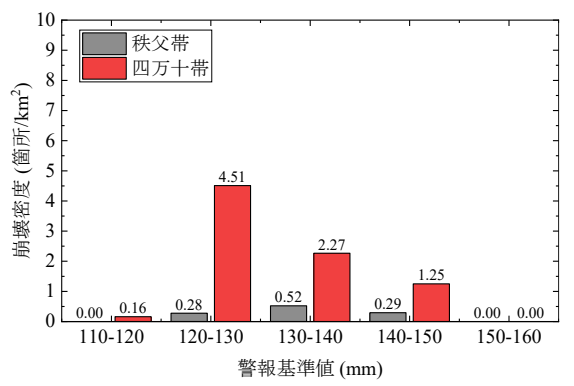

図 16 警報基準値と崩壊密度の関係

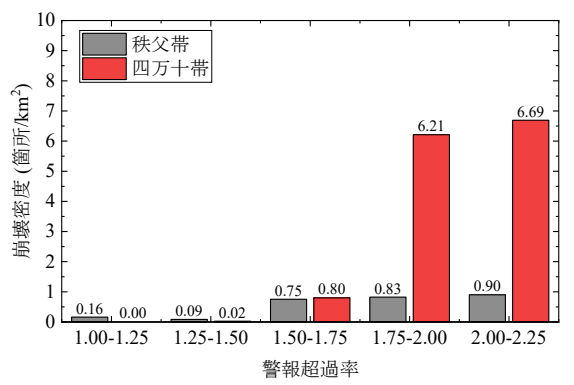

図 17 警報基準値に対する超過率と崩壊密度の関係

やや低く, 県内では土砂災害の危険性が相対的に高い地域 であることが示されている。

図 16 に判読範囲内における警報基準值と崩壊密度の関 係を地質帯毎に示す。秩父帯では崩壊数が少ないことから 明確な相関は得られていないものの，四万十帯では 110-120 mm の範囲を除くと単調減少の傾向にある。警報 基準值は災害履歴に応じて随時更新されることを考える と, 基準值が低い地域ほど崩壊が発生しや寸い傾向にある と単純に理解することができる。その一方で，災害の多発 地点においては, 崩壊し得る素因条件を満たす脆弱な斜面 の多くが過去の豪雨で既に崩壊している可能性も考えら れる。すなわち，基準值が低いほど土砂災害が発生しや寸 いとは一概に言えず，崩壊密度が相対的に低い基準值 110-120 mm の地域はこの条件に相当する可能性がある。 災害履歴に関寸る研究例は多くないが，平成 30 年 7 月豪 
雨と令和 2 年 7 月豪雨による土砂災害を比較し, 降雨指標 が同等以上であるにも関わらず土砂災害発生件数が大き く減少したことを報告した事例がある ${ }^{32) 。 ~}$

図 17 には, 判読範囲内における警報基準値に対する超 過率と崩壊密度の関係を示す。超過率は, 各基準地域メッ シュにおける 7 月 7 日 7:00 時点の土壤雨量指数を同メッ シュの警報基準值で除したものである。超過率は全 862 メ ッシュ中 860 メッシュで 1.0 を超えており，その最大值は 2.19 であった。いずれの地質帯においても超過率と崩壊密 度には単調増加の傾向が認められるものの, 土袞雨量指数 と崩壊密度の関係を求めた図 14 と比較すると, その相関 の強さには顕著な変化は見られない。これは, 図 2 の時刻 歴で示したように, 土壤雨量指数は一度の降雨ピークで $100 \mathrm{~mm}$ 近く上昇する場合もある中で, 判読範囲内におけ る警報基準值はわずかに $50 \mathrm{~mm}$ 程度の幅しか持たないこ とがその原因であると考えられる。すなわち，現状の警報 基準の設定は概政妥当ではあるものの, 今回のような猛烈 な降雨に対しては斜面崩壊の発生危険度を $1 \mathrm{~km}$ 四方の分 解能では必ずしも正確に表現できていないといえる。今回 の分析から認められた地質などの素因に応じた危険度の 違いを考慮した基準值への改良が今後必要であると考え られる。

\section{4. おわりに}

本研究では, 平成 30 年 7 月豪雨による愛媛県下での降 雨特性と斜面崩壊の特徵について整理するとともに, 斜面 崩壞発生地点の位置情報と解析雨量および XRAIN の雨量 データを活用し, 県南西部一帯の斜面崩壊の発生に影響し た降雨特性を分析した。得られた結果を以下に列挙寸る。

1. 今回の豪雨により, 降水量が例年少ない沿岸部におい て降水量の観測記録を多数更新した。特に, 県南西部 の西予市から宇和島市の一帯では, 7 月 7 日の 6:00 か ら 8:00 にかけて記録的な豪雨となり,この時間帯にお いて土砂災害の発生が相次いだ。

2. 県南西部で発災直後に撮影された約 $1,200 \mathrm{~km}^{2}$ の範囲 の空中写真から判読された計 882 箇所の崩壊発生地点 を地質帯毎に分類したところ, 斜面崩壊の発生密度は 四万十帯で高く, 分析対象面積が同程度である秩父帯 の約 5.6 倍に達した。

3. 空中写真の範囲内において, $1 \mathrm{~km}$ および $250 \mathrm{~m}$ 四方の メッシュ単位で短期降雨指標（1 時間降水量） と長期 降雨指標 (土壤雨量指数) の関係を求め, メッシュ内 における斜面崩壊の発生の有無に対して判別分析を 行った。その結果, 斜面崩壊が多発したとされる時間 帯において, 崩壊発生地点とそれ以外の地点で降雨指 標の分布に偏りが見られ, 判別分析の感度にも有意な 差が現れた。空間分解能の高い XRAIN の方が分布の 偏りはより明瞭であり, 土砂災害分析に対するXRAIN の活用可能性が示された。
4. 秩父帯, 四万十帯ともに降雨指標と崩壊密度には単調 増加の傾向があり, いずれの地質帯でも 1 時間降水量 60 80 mm, 土袞雨量指数 220 260 $\mathrm{mm}$ を境界値として, 崩壊密度は急増した。一方, この境界值以上では, 崩 壊密度はいずれの降雨指標でも四万十帯の方が極め て高く，境界值を超えた際の降水量に対寸る崩壊確率 の増加具合は地質帯で大きく異なることが明らかと なった。

5. 解析雨量から求めた土壤雨量指数と大雨警報 (土砂災 害）基準值を比較したところ, 現状の警報基準值の妥 当性が確認できた。今後, より詳細な分解能で土砂災 害の危険度を正確に評価するためには, 地質などの素 因を考慮していく必要性がある。

\section{参 考 文 献}

1) 気象庁: 平成30年7月豪雨（前線及び台風7号による大雨等）, 2018.（閲覽日2020年3月1日）

https://www.data.jma.go.jp/obd/stats/data/bosai/report/2018/2018071 3/jyun_sokuji20180628-0708.pdf

2) 国土交通省 : 平成30年7月豪雨による被害状況等について（第 52報），2019。（閲覧日2020年3月1日） http://www.mlit.go.jp/common/001268344.pdf

3) 愛媛県災害対策本部 : 平成30年7月豪雨による被害状況等につ いて (第100報)，2018．(閲覽日2020年3月1日) https://www.pref.ehime.jp/h12200/documents/higai100.pdf

4) 石黒聡士 : 南予地方の航空写真判読と空間分布，平成30年7月 豪雨愛媛大学災害調査団報告書, pp. 148-156, 2019.

5) 愛媛県 : 地域防災計画 (資料編)，1-2愛媛県の主な気象災害 （大正元年～平成27年）（防災危機管理課），2017。(閲覧日 2020年3月1日)

https://www.pref.ehime.jp/bosai/bosaikeikaku/documents/01kaigokir oku.pdf

6) 国土交通省河川局砂防部，気象庁予報部，国土交通省国土技術 政策総合研究所 : 国土交通省河川局砂防部と気象庁予報部の連 携による土砂災害警戒避難基淮雨量の設定手法（案），2005. (閲覽日2020年3月1日)

https://www.mlit.go.jp/river/shishin_guideline/sabo/dsk_tebiki_h170 6.pdf

7) 山本晴彦, 山崎俊成, 有村真吾, 原田陽子, 高山成, 吉越恆, 岩谷潔 : 2009年7月21日に山口県において発生した豪雨の特徴 と土砂災害の概要, 自然災害科学, Vol. 29, No. 4, pp. 471-485, 2011.

8) 加納誠二, 土田孝, 中川翔太, 海堀正博, 中井真司, 来山尚義 : 2009年に東広島市志和町内地区で発生した土砂災害の調査に ついて，地盤工学ジャーナル，Vol. 6, No. 2, pp. 243-259, 2011.

9）土田孝, 森脇武夫, 田中健路, 中井真司 : 2014年8月20日の広 島豪雨災害における雨量を用いた土砂災害危険度評価に関す る考察, 地盤工学ジャーナル, Vol. 11, No. 1, pp. 53-68, 2016.

10）上出定幸，土肥泰之，小泉圭吾，細木康夫，殿垣内正人，中辻 啓二: 降雨を考慮した斜面の崩壊危険度評価に関する考察, 地 盤工学ジャーナル，Vol. 5, No.1,pp. 159-168, 2010.

11) 田内裕人, 江種伸之, 平田健正 : 実効雨量および土壌雨量指数 から見た平成23年台風12号による土砂災害現場の水文地質特 性，第8回土砂災害に関するシンポジウム論文集，pp. 19-24, 2016.

12）石澤友浩，檀上徹 : 平成30年7月豪雨による土砂災害発生の推 定時刻における土袞雨量指数, 防災科学技術研究所主要災害調 查, Vol. 53, 2019.

13）気像業務支援センター: 解析雨量2018年1-9月, CD-ROM, 2018.

14) 気象業務支援センター：メッシュ平年值2010年降水量, 
CD-ROM， 2018.

15) 岡田憲治, 牧原康隆, 新保明彦, 永田和彦, 国次雅司, 斉藤清 : 土壤雨量指数, 天気, Vol. 48, No. 5, pp.349-356, 2001.

16) 愛媛県: 平成30年7月豪雨警戒避難体制強化のための土砂災害 対策検討委員会報告書，2019。（閲覧日2020年3月1日） https://www.pref.ehime.jp/h40700/documents/04-2syou.pdf

17) 松山地方気象台：平成30年7月5日から8日にかけての梅雨前線 による大雨について (愛媛県の気象速報)，2018。(閲覧日2020 年3月1日)

https://www.jma-net.go.jp/matsuyama/saigai/H30/sokuho20180709. pdf

18) 気象庁: 平成30年7月豪雨及び7月中旬以降の記録的な高温の特 徵と要因について，2018。(閲覧日2020年3月1日)

https:/www.jma.go.jp/jma/press/1808/10c/h30goukouon20180810.p df

19）国土交通省四国地方整備局，国土地理院：四国地方の古地理に 関する調查報告書 川と人との歴史ものがたり，2003.（閲覧 日2020年3月1日）

https://www.skr.mlit.go.jp/kasen/data/hitotokawatonomonogatari.pdf

20) Mori, S. and Ono, K.: Landslide Disasters in Ehime Prefecture Resulting from the July 2018 Heavy Rain Event in Japan, Soils and Foundations, Vol. 59, pp. 2396-2409, 2020.

21) 国土地理院 : 平成30年7月豪雨に伴う崩壊地等分布図（大洲地 区・宇和島地区），2018。（閲覧日2020年3月1日） https://www.gsi.go.jp/common/000216832.pdf

22) 川崎一歩, 森伸一郎 : 平成30年7月豪雨による斜面崩壊の崩土 流下特性, 第54回地盤工学研究発表会発表講演集 CD-ROM, pp. 1809-1810, 2019.

23）産総研地質調査総合センター：20万分の1日本シームレス地質 図 V2, データ更新日2019年6月5日, https://gbank.gsj.jp/seamless/,
2019.

24）寺田秀樹，中谷洋明 : 土砂災害警戒避難基準雨量の設定手法方 法，国土交通省国土技術政策総合研究所資料，Vol. 5, 2001.

25) Nakai, S., Sasaki, Y., Kaibori, M., and Moriwaki, T.: Rainfall Index for Warning and Evacuation against Sediment-Related Disaster; Reexamination of Rainfall Index $\mathrm{R}_{\mathrm{f}}$, and Proposal of R', Soils and Foundations, Vol. 46, pp. 465-475, 2006.

26) データ統合・解析システム DIAS : XRAIN 原データ検索・ダウ ンロードシステム，2019.（閲覧日2018年7月9日）

https://www.diasjp.net/service/xrain-data/

27）土屋修一，川崎将生，五道仁実 : 降雨減衰補正と合成雨量作成 手法の改良による XRAIN 観測雨量の精度向上，土木学会論文 集 B1（水工学），Vol. 71, No.4,pp. I_457-I_462, 2015.

28）愛媛県土木部：愛媛県河川・砂防情報システム，2020.（閲覧 日2020年3月1日)

http://kasensabo.pref.ehime.jp/dosha/frameset.html?DoshasaigaiKike ndoJouhou.do

29）木村誇，若月強，山田隆二，井口隆 : 平成30年7月豪雨により 愛媛県南西部で発生した斜面崩壊の規模と分布の特徵, 防災科 学技術研究所主要災害調查, Vol. 53, 2019.

30) 森伸一郎:平成30年7月豪雨における愛媛県の斜面災害の特徴, 第54回地盤工学研究発表会発表講演集 CD-ROM, pp. 1807-1808, 2019.

31) 気象庁: 大雨警報・注意報の土壌雨量指数基準值 $(1 \mathrm{~km}$ 四方), 2010. (閲覧日2020年3月1日)

https://www.jma.go.jp/jma/kishou/know/kijun/index_shisu.html

32）三浦誠司，小野耕平，森伸一郎：XRAIN を活用した令和2年7 月豪雨による松山市の土砂災害の分析，令和 2 年度地盤工学会 四国支部技術研究発表会講演概要集 CD-ROM, 2020.

(2020.8.31 受付) 


\title{
Analysis of rainfall characteristics for landslide disasters in southwestern part of Ehime Prefecture resulting from the July 2018 heavy rain event
}

\author{
Kohei $\mathrm{ONO}^{1}$ and Shinichiro MORI ${ }^{1}$ \\ 1 Graduate School of Science and Engineering, Ehime University
}

\begin{abstract}
In July 2018, a large number of landslide disasters occurred in the southwestern part of Ehime Prefecture, resulting in enormous damage and many casualties. Firstly, this paper summarized the characteristics of the rainfall event and the landslide disasters throughout the prefecture. The statistics revealed that the number and the types of landslides strongly depended on the geology. Secondly, the rainfall characteristics that caused landslides in the southwestern part of the prefecture were analyzed by using the coordinates of each slope failure and the local rainfall data based on the radar/rain gauge-analyzed precipitation and XRAIN. The discriminant analysis of the relationship between the hourly rainfall and the soil water index showed a significant bias in the distribution of the rainfall indices in response to the occurrence of the slope failures, and that each rainfall index had a boundary value at which the number of slope failures increased rapidly. It was also revealed that the density of slope failure beyond the boundary value of each rainfall index clearly differs depending on the geology.
\end{abstract}

Key words: Slope Failure, Radar/rain gauge-analyzed precipitation, XRAIN, Soil Water Index, Discriminant Analysis 